\title{
EEKTIFITAS MEDIA PEMBELAJARAN STOPMOTION BERBASIS INQUIRY DALAM PEMBELAJARAN SEJARAH DI ERA REVOLUSI INDUSTRI 4.0
}

\author{
Sumardi, Nurul Umamah, Azizah \\ Email: sumardi.fkip@ unej.ac.id \\ Pendidikan Sejarah, Fakultas Keguruan dan Ilmu Pendidikan, Universitas Jember \\ (UNEJ), Jln. Kalimantan 37, Jember 68121
}

\begin{abstract}
Abstrak
Era Revolusi Industri 4.0 menjadi era baru yang menggunakan banyak teknologi virtual dan canggih. Oleh karena itu perlu dikembangkan media pembelajaran yang memenuhi tuntutan kurikulum Revolusi Industri 4.0 dan kurikulum 2013. Tujuan dari penelitian ini adalah untuk mengetahui efektivitas media pembelajaran stopmotion berbasis inquiry dalam pembelajaran sejarah. Jenis penelitian ini adalah penelitian eksperimen dengan pola one group pretest-postest design.Teknik pengumpulan data yang digunakan dalam penelitian ini adalah observasi, angket, wawancara, dan tes. Efektivitas produk dapat dilihat dari skor gain. Uji coba kelompok kecil memperoleh skor gain 0,9 dengan kualifikasi memiliki efektivitas tinggi dan uji coba kelompok besar memperoleh skor gain 0,8 dengan kualifikasi memiliki efektivitas tinggi. Berdasarkan hasil yang disajikan, media pembelajaran stopmotion berbasis inquiry dapat digunakan sebagai media pembelajaran sejarah di sekolah untuk siswa.
\end{abstract}

Kata Kunci: Efektifitas, media pembelajaran stopmotion, inquiry, pembelajaran sejarah, era revolusi industri 4.0

\section{Pendahuluan}

Era Revolusi Industri 4.0 menjadi era baru yang banyak menggunakan teknologi virtual dan canggih. Setiap bidang keilmuan dan kehidupan saat ini telah dipengaruhi oleh perkembangan teknologi baru yang mengintegrasikan unsur fisik, digital dan biologis (Sutirman, 2018:3). Perkembangan teknologi di era Revolusi Industri 4.0 berdampak pada bidang pendidikan yang membuat pembelajaran tidak hanya dilakukan di ruang kelas sekolah, tetapi dapat pula berupa pembelajaran berbantuan komputer yang inovatif.

Pembelajaran sejarah pada kurikulum 2013 memiliki prinsip pembelajaran sesuai Permendikbud Nomor 60 tahun 2016 yang menuntut peserta didik memiliki pemahaman materi yang tinggi dan peserta didik dapat menemukan sendiri informasi dalam kegiatan pembelajaran. Pendidik harus menjadi fasilitator dalam proses pembelajaran (Munadi, 2012:36-37). Pembelajaran sejarah yang dikehendaki kurikulum 2013 adalah pembelajaran yang kreatif dan inovatif dengan menggunakan pendekatan saintifik untuk mencapai tujuan pembelajaran 
(Kemendikbud, 2016). Pembelajaran sejarah ini senafas dengan tuntutan era Revolusi Industri 4.0 yang juga menghendaki pembelajaran yang kreatif dan inovatif dengan memanfaatkan kemajuan teknologi.

Keterampilan abad 21 atau lebih dikenal dengan istilah 4C (Communication, collaboration, critical thinking and problem solving, dan creativity and innovation) mutlak diperlukan pada era Revolusi Industri 4.0 (Zuhri:2017). Keterampilan 4C telah menjadi tuntutan di dalam Kurikulum 2013 sehingga Pembelajaran yang dilakukan haruslah mengimplementasikan 4C. implementasi kurikulum 2013 menggunakan 4C dalam pembelajaran sejarah harus dilakukan dengan menggunakan metode hingga media pembelajaran yang tepat.

Kurikulum 2013 menggunakan pendekatan saintifik. Salah satu metode pembelajaran yang mengunakan pendekatan saintifik adalah metode inquiry terbimbing. Inquiry berasal dari kata to inquire yang berarti ikut serta dalam mengajukan pertanyaan-pertanyaan, mencari informasi, dan melakukan penyelidikan (Suryandari, dkk, 2016:2, Fairuzabadi, dkk, 2017:101). Inquiry memiliki sintaks-sintaks yang dapat diimplemtasikan 4C di dalamnya, sehingga sesuai dengan tuntutan kurikulum 2013 dan era Revolusi Industri 4.0.

Metode pembelajaran inquiry adalah salah satu metode pembelajaran yang menitikberatkan proses pembelajaran pada keterlibatan siswa secara langsung dan maksimal (Sugiarta dan Ratnani, 2017:14). Metode pembelajaran inquiry sebagai sebuah cara pendidik dalam membimbing peserta didik membangun pengetahuan dan pemahaman yang mendalam mengenai materi pelajaran, membekali dan mengarahkan peserta didik menuju pembelajaran yang bebas (Kuhlthan \& Todd dalam Zahro, Umamah, Suranto, 2014:2). Metode pembelajaran inquiry memberikan kesempatan kepada peserta didik untuk terlibat langsung dalam pemecahan suatu masalah, sehingga pengalaman yang didapat peserta didik dapat bermakna (Zahro, Umamah, Suranto, 2014:2).

Media pembelajaran merupakan bagian dari metode pembelajaran. Metode adalah suatu prosedur pembelajaran yang dipilih untuk membantu peserta didik untuk mencapai tujuan atau internalisasi isi atau pesan (Umamah, 2018:175). Media pembelajaran sejarah bermanfaat sebagai alat bantu mengajar untuk membantu dan memudahkan peserta didik untuk memvisualisasikan suatu peristiwa sejarah sedemikian rupa, sehingga peserta didik lebih mudah untuk menangkap serta menghayati gambaran peristiwa sejarah tersebut (Widja, 1989:60). Menurut Soewarso (2000:102), penggunaan media pembelajaran mutlak diperlukan dalam 
pembelajaran sejarah. Penggunaan media tertentu dalam pembelajaran diperlukan karena pada hakikatnya suatu media dalam pembelajaran merupakan cara yang teratur dan terpikir secara sistematis untuk mencapai suatu tujuan pembelajaran serta untuk memperoleh kemampuan dalam mengembangkan efektivitas belajar yang dilakukan oleh pendidik dan peserta didik.

Media yang dapat dipadukan dengan model pembelajaran inquiry adalah media video Stopmotion (Fairuzabadi, 2017:101). Stop motion merupakan teknik animasi yang memberikan efek suatu gambar menjadi bergerak. Animasi berasal dari kata kerja latin animare yang berarti membuat menjadi hidup atau mengisi dengan nafas (Wright, dalam Nugroho, 2016:16). Animasi mampu merekonstruksi suatu hal menjadi hal lainnya yang lebih hidup. Media pembelajaran video dengan menggunakan teknik animasi stopmotion memfasilitasi peserta didik dalam pembelajaran sejarah untuk memiliki kemampuan $4 \mathrm{C}$ terutama kemampuan creativity and innovation.

Penelitian terhadulu menyatakan media pembelajaran dapat efektif meningkatkan hasil belajar (Mahulae, 2017; Wulandari, Na'im, Sumarno, 2018; Suliningsih, Na'im, Sumardi, 2018). Hasil penelitian juga relevan dengan penelitian yang dilakukan menunjukkan metode inquiry learning efektif meningkatkan hasil belajar (Andriani, 2016; Zahro, Umamah, Suranto, 2014; Dwijayanti, Na'im, Umamah, 2015; Rahman, Sumardi, Handayani, 2013) Penelitian tersebut menunjukkan model pembelajaran inquiry efektif digunakan dalam pembelajaran karena peserta didik dituntut untuk aktif dalam kegiatan pembelajaran secara individu maupun kelompok serta dapat mengembangkan kemampuan kognitif, psikomotor, dan afektif peserta didik.

penelitian ini memiliki tujuan mengetahui efektivitas media pembelajaran stopmotion berbasis inquiry pada mata pelajaran Sejarah Indonesia kelas X SMA. Adapun beberapa asumsi dalam pengembangan media pembelajaran ini, antara lain: (1) media pembelajaran stopmotion berbasis inquiry efektif digunakan pada mata pelajaran sejarah. Peserta didik juga dapat menambah pengetahuan mengenai materi "berbagai teori masuknya agama dan kebudayaan Islam ke Indonesia"; (2) media pembelajaran stopmotion didesain dan disusun secara sistematis untuk membantu pendidik dan peserta didik.

\section{Metode Penelitian}

Jenis penelitian ini adalah penelitian eksperimen dengan pola one group pretest-posttest design. Teknik pengumpulan data pada penelitian ini menggunakan cara observasi, kuesioner, 
wawancara, dan tes. Subjek penelitian ini terdiri dari 1 pendidik mata pelajaran sejarah dan 33 peserta didik kelas X di salah satu SMA Negeri di Kabupaten Jember. Teknik analisis data pada penelitian ini adalah teknik analisis kualitatif dan kuantitatif. Analisis data kualitatif didapat dari hasil observasi, kuesioner, saran ahli serta dokumentasi sekolah. Analisis data kuantitatif digunakan untuk mendefinisikan kualitas media pembelajaran yang dikembangkan sesuai hasil pembelajaran peserta didik setalah menggunakan media pembelajaran stopmotion berbasis inquiry sebagai media pembelajaran.

Data yang digunakan untuk mengetahui efektivitas penggunaan media pembelajaran stop motion berbasis inquiry diperoleh melalui pre-test dan post-test yang diberikan kepada peserta didik sebelum dan sesudah menggunakan media stop motion berbasi inquiry dalam pembelajaran sejarah. Efektivitas media pembelajaran dapat mengacu pada teori Hake mengenai Gain ternomalisasi. Richard R. Hake memaparkan bahwa gain score adalah selisih antara nilai tes akhir (post-test) dengan tes awal (pre-test). Metode Gain ternimalisasi dapat dilakukan untuk mengetahui peningkatan atau penurunan tingkat pemahaman peserta didik dalam proses pembelajaran atau yang biasa disebut sebagai efektivitas. Efektivitas media pembelajaran dapat mengacu pada teori Hake mengenai Gain ternomalisasi. Richard R. Rumus nilai Gain ternormalisasi menurut Hake (1999) adalah sebagai berikut.

$\mathrm{g}=\frac{\text { Skor Posttest-Skor Pretest }}{\text { Skor Maksim } / \text { K } \mathrm{m} \text {-Skor Pretest }}$

keterangan:

$\mathrm{g}=$ nilai gain ternormalisasi

Skala nilai yang digunakan pada data Gain ternormalisasi ditunjukkan pada table berikut. Table 2. Kriteria Gain Ternormalisasi

Skor Gain Ternormalisasi Kriteria Gain Ternormalisasi

$\begin{array}{cc}0,7<\mathrm{g}<1 & \text { Efektivitas Tinggi } \\ 0,3 \leq \mathrm{g} \leq 0,7 & \text { Efektivitas Sedang } \\ 0<\mathrm{g}<0,3 & \text { Efektivitas Rendah }\end{array}$

(Sumber: Hake, 1999)

\section{Hasil Penelitian}

Efektivitas media pembelajaran stopmotion berbasis inquiry dapat dilihat dari hasil yang diperoleh dalam uji coba kelompok kecil dan uji coba kelompok besar. Materi yang digunakan 421 | Seminar Nasional Sejarah ke 4 Jurusan Pendidikan Sejarah Universitas Negeri Padang 
dalam media pembelajaran stopmotion berbasis inquiry ini adalah Kompetensi Dasar (KD) mata pelajaran sejarah dalam kurikulum 2013 yaitu KD kelas X 3.7 yang berbunyi "Menganalisis Berbagai Teori Masuknya Agama dan Kebudayaan Islam ke Indonesia”. Media pembelajaran stopmotion berbasis inquiry dinyatakan layak dan efektif untuk digunakan dalam pembelajaran sejarah karena telah melalui tahap uji produk.

Tahap uji coba produk yang dilakukan meliputi uji coba pengguna, uji coba kelompok kecil, dan uji coba kelompok besar. Uji coba pengguna dilakukan kepada pendidik bertujuan untuk mengetahui kualitas media pembelajaran stopmotion berbasis inquiry berdasarkan kriteria kelayakan produk diperoleh sebesar $88 \%$ artinya produk sangat baik dan tidak perlu revisi. Uji coba kelompok kecil dan kelompok besar digunakan untuk mengetahui efektivitas media pembelajaran stopmotion berbasis inquiry.

Hasil penelitian mengenai keefektivan media pembelajaran stopmotion berbasis inquiry ditujukkan dengan hasil pre-test dan post-test. Hasil uji coba tersebut dihasilkan dari uji coba kelompok kecil dan uji coba kelompok besar. Hasil rata-rata pre-test dan post-test pada uji coba kelompok besar dan uji coba kelompok kecil dapat dilihat pada diagram berikut.

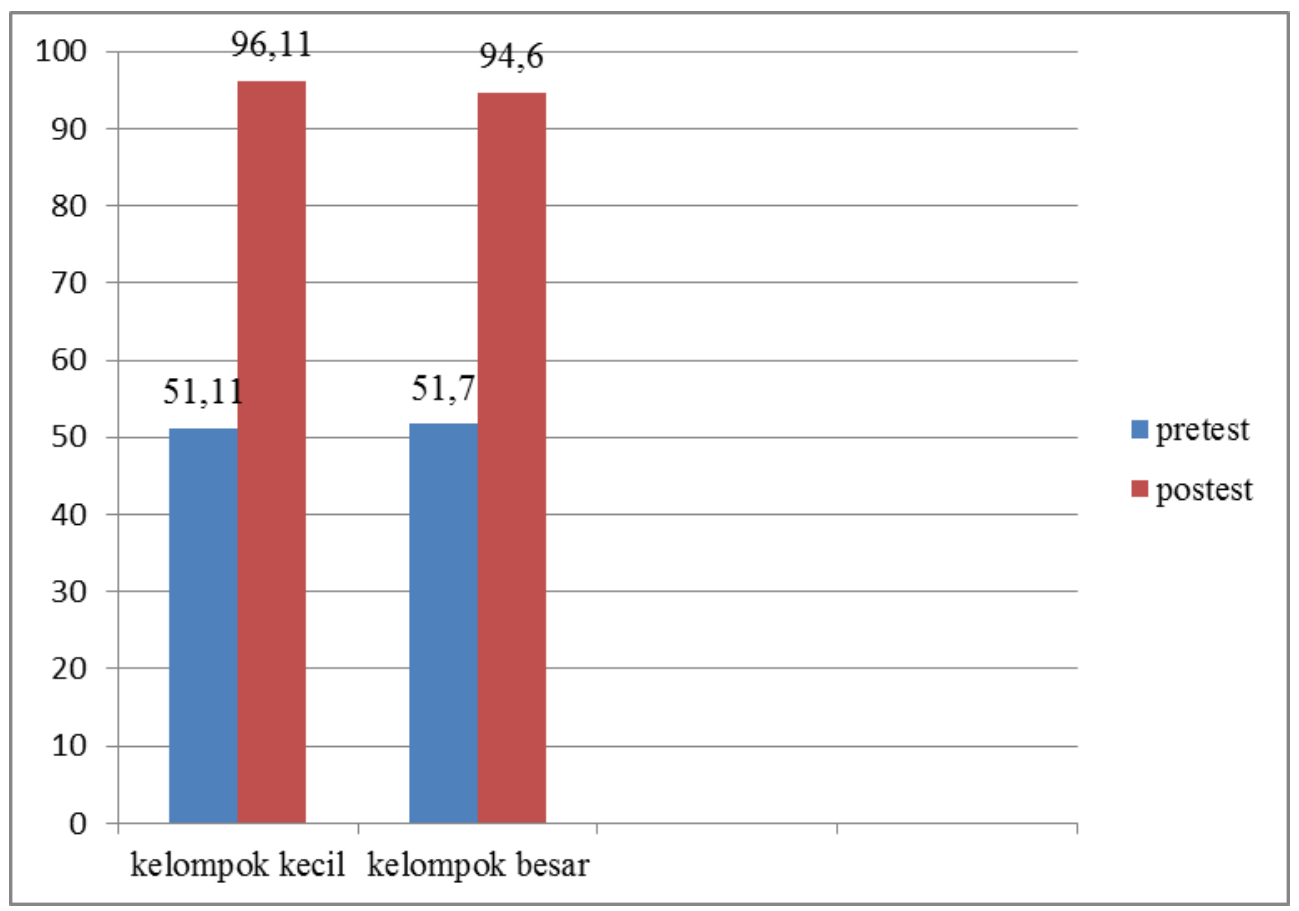

Gambar 1. Diagram Hasil rata-rata pre-testdan post test Uji Coba Kelompok Kecil dan Uji Coba Kelompok Besar 
Hasil nilai pre-test dan post-test uji coba kelompok kecil akan digunakan untuk mengukur tingkat efektivitas pembelajaran sejarah dengan menggunakan media pembelajaran stopmotion berbasis inquiry. Tingkat efektivitas tersebut dapat diketahui dengan menggunakan rumus gain ternormalisasi dimana terdapat selisih antara nilai post-test dan nilai pre-test. Berikut merupakan rumus yang digunakan.

$\mathrm{g}=\frac{\text { Skor Posttest }- \text { Shor Prete }}{\text { Skor } \text { Maksimum }}$

$g=\frac{865-460}{900-460}$

$g=\frac{405}{440}$

$\mathrm{g}=0,9($ Hake, 1999$)$

Berdasarkan perhitungan dari rumus di atas diperoleh hasil sebesar 0,9 sehingga dapat disimpulkan bahwa efektivitas produk yang dikembangkan termasuk memiliki efektivitas tinggi.

Hasil dari nilai pre-test dan post-test uji coba kelompok besar akan digunakan utuk mengukur tingkat efektivitas pembelajaran sejarah dengan menggunkan media pembelajaran stopmotion berbasis inquiry. Tingkat efektivitas tersebut dapat diketahui dengan menggunakan rumus gain ternormalisasi yang terdapat selisih antara nilai pre-test dan nilai post-test. Berikut rumus yang digunakan.

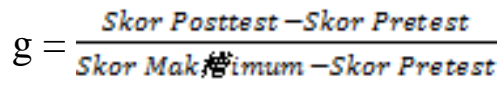

$\mathrm{g}=\frac{3046-1695}{3300-1695}$

$\mathrm{g}=\frac{1351}{1905}$

$\mathrm{g}=0,8($ Hake, 1999$)$

Berdasarkan perhitungan dari rumus diatas diperoleh hasil sebesar 0,8 sehingga dapat disimpulkan bahwa efektivitas produk yang dikembangkan termasuk memiliki keefektivan tinggi. Hasil tersebut menunjukkan bahwa terdapat peningkatan hasil belajar peserta didik setelah menggunakan media pembelajaan stopmotion berbasis inquiry. 
Penelitian yang dilakukan relevan dengan penelitian terdahulu yang menyatakan media pembelajaran dapat meningkatkan hasil belajar (Mahulae, 2017; Wulandari, Na'im, Sumarno, 2018; Suliningsih, Na'im, Sumardi, 2018). Hasil penelitian juga relevan dengan penelitian yang dilakukan menunjukkan metode inquiry learning dapat meningkatkan hasil belajar (Andriani, 2016; Zahro, Umamah, Suranto, 2014; Dwijayanti, Na'im, Umamah, 2015; Rahman, Sumardi, Handayani, 2013) Penelitian tersebut menunjukkan model pembelajaran inquiry efektif digunakan dalam pembelajaran karena peserta didik dituntut untuk aktif dalam kegiatan pembelajaran secara individu maupun kelompok serta dapat mengembangkan kemampuan kognitif, psikomotor, dan afektif peserta didik.

Keefektivan media pembelajaran stopmotion berbasis inquiry dapat diketahui melalui tingkat keberhasilan dari suatu proses pembelajaran. Nuraeni (2010) memaparkan pembelajaran dapat dikatakan efektif meningkatkan hasil belajar apabila secara statistik hasil belajar siswa menunjukkan perbedaan yang signifikan antara pemahaman awal dengan pemahaman setelah pembelajaran yang ditujukkan dengan gain yang signifikan. Suryosubroto (2009) berpendapat bahwa ketuntasan dalam belajar minimal 85\% peserta didik mampu mencapai KKM (Kriteris Ketuntasan Minimal).

Hasil belajar yang didapat oleh peserta didik setelah menggunakan media pembelajaran stopmotion berbasis inquiry dapat dikatakan tuntas. Hal tersebut didasarkan pada nilai post-test peserta didik tidak ada yang memperoleh nilai dibawah KKM. Berdasarkan perolehan nilai peserta didik dan hasil dari penelitian-penelitian terdahulu dapat disimpulkan bahwa media pembelajaran stopmotion berbasis inquiry yang dikembangkan memiliki efektivitas yang tinggi dan efektif digunakan dalam proses pembelajaran.

\section{Simpulan}

Berdasarkan pemaparan hasil penelitian efektivitas media pembelajaran stopmotion berbasis inquiry, maka dapat diambil kesimpulan penggunaan media pembelajaran stopmotion berbasis inquiry efektif digunakan untuk pembelajaran. Efektivitas media pembelajaran stopmotion berbasis inquiry dapat dilihat dari persentase yang diperoleh dalam uji coba kelompok kecil dan uji coba kelompok besar. Pada uji coba kelompok kecil diperoleh efektivitas produk yang dilihat dari perolehan gain ternormalisasi sebesar 0,9 dengan kualifikasi memiliki 
efektivitas tinggi dan pada uji kelompok besar efektivitas produk yang dilihat dari perolehan gain ternormalisasi sebesar 0,8 dengan kualifikasi memiliki efektivitas tinggi.

\section{DAFTAR PUSTAKA}

Andriani, V. 2016 The Effectiveness of Inquiry Learning Metod to Enhance Students' Learning Outcome: A Theoritical and Empirical Review. Journal od Education and Practice ISSN 2222-1735 (Paper) ISSN 2222-288X (Online) Vol. 7 No. 32016

Dwijayanti, L., Moh Na'im., Nurul Umamah. 2015. Penerapan pendekatan scientific dengan metode inquiry untuk meningkatkan hasil belajar sejarah peserta didik kelas XI IPS 1 SMA Negeri 1 Tenggarang. Artikel Ilmiah Mahasiswa (1) 1-8

Fairuzabadi, A, et al. 2017. Pengembangan Model Pembelajaran Inkuiri Terbimbing dengan Video berbasis Kontekstual dalam Pembelajaran IPA pada Materi Suhu dan Pengukurannya di SMP. Jurnal Pendidikan Fisika Vol 6 No. 1, Maret 2017, hal 100-106

Hasan, H. 2003. Problematika Pembelajaran Seajarah. Bandung: Jurusan Pendidikan Sejarah, FPIPS-UPI

Hake, R. 1999. Analyzing Change/Gain scores. [Online]. Diakses dari www.physics.indiana.edu/ sdi/AnalyzingChange-Gain.pdf pada tanggal 15 Februari 2019, Jam 12.58 WIB

Kemendikbud. 2016. Silabus Mata Pelajaran Sekolah Menengah Atas/Sekolah Kejuruan/Madrasah Aliyah/Madrasah Aliyah Kejuruan (SMA/SMK/MA/AK): Mata Pelajaran Sejarah Indonesia. Jakarta: Kemendikbud

Mahulae, P, dkk. 2017. The Effect of Inquiry Training Learning Model Using PhET Media and Scientific Attitude on Student' Science Proses Skills. IOSR Journal of Research \& Method in Education e-ISSN: 2320-7388, p-ISSN: 2320-737X Vol. 7, Issue 5 Ve. 1 (Sep. - Oct. 2017), PP 24-29.

Munandi,Y. 2012. Media Pembelajaran. Jakarta : GaungPersada.

Nugroho, R. 2016. Media pembelajaran gambar dengan Animasi Stop motion pada Mata Pelajaran Sejarah Kelas XI IPS di SMA Negeri 1 Bukitkemuning Tahun Pelajaran 2015/2016. Skripsi: Universita Lampung

425 | Seminar Nasional Sejarah ke 4 Jurusan Pendidikan Sejarah Universitas Negeri Padang 
Priansa, 2015. Menejemen Peserta didik Dan Model Pembelajaran. Bandung: Alfabeta

Rahman, F., Sumardi., Handayani, S. 2013. Implementasi Metode Inquiry untuk Meningkatkan Proses dan Hasil Pembelajaran Sejarah di SMA Rambipuji Jember Kelas X 5 2012/2013. Artikel Hasil Penelitian Mahasiswa Universitas Jember

Sayono, J. 2013. Pembelajaran Sejarah di Sekolah: dari Pragmatis ke Idealis. Jurnal Sejarah dan Budaya. Tahun ketujuh, No. 1, Juni 2013

Sugiarto, MM dan Dewa, Ayu. 2017. Penerapan Model Pembelajaran Inkuiri dengan Media Pembelajaran Video Partisipasi Terhadap keterampilan Proses Sains SMA Negeri 7 Denpasar. Jurnal Santiaji Pendidikan. ISSN : 2087-9016 Vol 7, No. 1, Januari 2017

Sutirman. 2018. Inovasi pembelajaran Kearsipan Digital di Era Industri 4.0. Orasi Ilmiah disampaikan pada Upacara Dies natalis ke-7 Fakultas Ekonomi Universitas Negeri Yogyakarta. Dipublikasikan http://www.researchgate. net/publica $\underline{\text { tion/327049611 }}$

Suryandari, dkk. 2016. Pengembangan Media Pembelajaran Menggunakan Video Dokumenter Berbasis Inquiry Terbimbing Berorientasi pada Motivasi Belajar Siswa. Jurnal Inkuiri. ISSN: 2252-7893, vol 5, No. 1, 2016 (hal 85-94)

Umamah, N. Kemampuan Guru dalam Mengembangkan Desain Pembelajaran IPS SD Se-eks Kotatif Jember Tahun 2008. Jurnal Ilmu Pengetahuam Sosial, ISSN 1411-5352, Vol X No. 4 Oktober 2008

Umamah, N. 2018. Perencanaan pembelajaran. Jember: Universitas Jember

Wulandari, P., Na'im, M., Sumarno. 2018. Pengembangan Media Pembelajaran Video Dokumenter Menggunakan Model 4D pada Mata Pelajaran Sejarah Kelas XI SMA. Tidak Diterbitkan. Skripsi. Jember: Universitas Jember

Zaenal, A. 2012. Pengembangan media Video Pembelajaran Kelas IX SMPN 1 Mojowarno Jombang. Jurnal-online.um.ac.id

Zahro, A., Umamah, N., Suranto. 2014. Penerapan Metode Pembelajaran InquiryTerbimbing (Guided Inquiry) untuk Meningkatkan Kreativitas dan Hasil Belajar Sejarah Peserta Didik Kelas XI-IIS 2 SMA Negeri 1 Gambiran Tahun Ajaran 2014/2015. Artikel Ilmiah Mahasiswa Universitas Jember 
Zuhri, M. 2017. Pengembangan Keterampilan 4C Melalui Pembuatan Film Pendek pada Siswa Kelas XI SMA Negeri 2 Boyolali Tahun Pelajaran 2016/2017. Naskah Best Practice Olimpiade Guru Nasional 2017 